\title{
Purification and partial characterization of serine alkaline metalloprotease from Bacillus brevis MWB-01
}

Folasade M Olajuyigbe ${ }^{*}$ and Ayodele M Falade

\begin{abstract}
Background: Proteases from bacteria are among the most important hydrolytic enzymes that have been studied due to their extracellular nature and high yield of production. Of these, alkaline proteases have potential for application in detergent, leather, food, and pharmaceutical industries. However, their usefulness in industry is limited by low activity and stability at high temperatures, extreme $\mathrm{pH}$, presence of organic solvents and detergent ingredients. It is therefore very crucial to search for new alkaline proteases with novel properties from a variety of microbial sources.
\end{abstract}

Results: In the present study, 21 Bacillus species isolated from organic waste sites were screened for proteolytic activity on casein agar. Bacillus brevis MWB-01 exhibited highest proteolytic activity with a clear zone diameter of $35 \mathrm{~mm}$. Production of protease from B. brevis MWB-01 was investigated in optimized media after $48 \mathrm{~h}$ of cultivation with shaking $(180 \mathrm{rpm})$ at $37^{\circ} \mathrm{C}$. The protease was partially purified in a two-step procedure using ammonium sulphate precipitation and gel filtration chromatography on Sephadex G-200 column. The enzyme was purified 2.1 -fold with yield of $4.6 \%$. The purified protease had optimum temperature of $40^{\circ} \mathrm{C}$ with relative activity of about $50 \%$ at $50^{\circ} \mathrm{C}$ and was uniquely stable up to $60^{\circ} \mathrm{C}$ after $30 \mathrm{~min}$ of incubation exhibiting $63 \%$ residual activity. The enzyme had optimum pH of 8.0 and remarkably showed relative activity above $70 \%$ at pH 9.0 to 11.0 and $53 \%$ at $\mathrm{pH} 12.0$, respectively and was very stable over a wide $\mathrm{pH}$ range (6.0 to 12.0). $\mathrm{Ca}^{2+}$ and $\mathrm{Mn}^{2+}$ increased protease activity with $9.8 \%$ and $3.5 \%$, respectively; $\mathrm{Hg}^{2+}$ and $\mathrm{Zn}^{2+}$ strongly inhibited protease activity by $89 \%$ and $86 \%$. The almost complete inhibition of the enzyme by phenylmethylsulphonyl fluoride (PMSF) and ethylene diamine tetra acetic acid (EDTA) confirmed the enzyme as a serine metalloprotease. The enzyme had highest compatibility with Sunlight, a commercial laundry detergent.

Conclusion: The characteristics of purified protease from B. brevis MWB-01 reveal the enzyme as a thermotolerant serine alkaline metalloprotease compatible with detergent formulation aids. Results suggest that protease from $B$. brevis MWB-01 is a good bioresource for industrial applications.

Keywords: Serine alkaline metalloprotease; Bacillus brevis; Purification; Characterization

\section{Background}

Proteases have a variety of applications in detergent, pharmaceutical, leather, and food industries [1-3]. Globally, proteases constitute the largest product segment of industrial enzymes, accounting for about $60 \%$ of the total worldwide enzyme sales [4,5]. Bacterial proteases are the most widely exploited when compared with fungal, * Correspondence: folajuyi@futa.edu.ng Nigeria plants, animal, and fungal proteases because of their extracellular nature and high yield of production; however, their usefulness is limited by various physicochemical factors, such as enzyme instability at high temperatures, extreme $\mathrm{pH}$, presence of organic solvents, anionic surfactant and oxidizing agents, and need for co-factors [6].

Ideally, alkaline proteases used in detergent formulation should demonstrate high level of activity and stability over a broad range of $\mathrm{pH}$ and temperature, possess broad substrate specificity and be active in the presence of detergent ingredients, such as surfactants, bleaching 
agents, fabric softeners, and other formulation aids [7]. Hence, it is imperative to search for new alkaline proteases with desirable properties for commercial viability from various bacterial sources.

Recently, we reported purified thermostable alkaline proteases from Bacillus licheniformis LHSB-05 isolated from hot spring [8] and Bacillus coagulans PSB-07 isolated from poultry litter site [9]. In this present study, 21 proteolytic Bacillus species isolated from organic waste sites were identified and Bacillus brevis MWB-01 was selected based on zone of clearance on casein agar. $B$. brevis produced protease under submerged conditions and the protease was purified and characterized.

This paper presents characteristics of alkaline protease from $B$. brevis MWB-01 which demonstrate the viability of the enzyme as good bioresource for industrial applications.

\section{Methods}

\section{Materials}

Sephadex G-200, bovine serum albumin (BSA), ethylene diamine tetra acetic acid (EDTA), casein, $\beta$-mercaptoethanol, phenyl methyl sulphonyl fluoride (PMSF) and media components were products of Sigma-Aldrich, St Louis, MO, USA. All other chemicals used were of analytical grade and obtained from Fisher Scientific (Waltham, MA, USA). Commercial laundry detergents used were Omo and Sunlight from Unilever (Rotterdam, Netherlands); Ariel was a product of Procter and Gamble (Cincinnati, $\mathrm{OH}$, USA).

\section{Isolation and identification}

Sub-soil samples were collected aseptically from organic waste sites which included beds of effluent treatment plants of selected brewery, dairy and food industries, drainage from abattoir, poultry litter site and locust bean processing farm in the south western part of Nigeria for the preparation of initial culture. These were subcultured to obtain pure isolates of Bacillus species using the method of Aslim et al. [10]. The Bacillus species were identified based on methods described in Bergey's Manual of Systematic Bacteriology [11,12].

\section{Screening for proteolytic activity of Bacillus species}

The identified bacterial isolates were plated onto casein milk agar plates and were incubated at $37^{\circ} \mathrm{C}$ for $24 \mathrm{~h}$. $15 \% \mathrm{HgCl}_{2}$ in $20 \% \mathrm{HCl}$ was added to the plates and examined for clearing zone around the bacterial growth. The diameter of the zone was measured in millimeters. A clear zone of casein hydrolysis gave an indication of protease-producing organisms. Depending on the zone of clearance, B. brevis MWB-01 was selected for further studies.

\section{Production of protease}

Production of protease from Bacillus brevis MWB-01 was carried out in a culture medium containing the following: $0.5 \%$ glucose, $0.75 \%$ peptone, and $5 \%$ salt solution made up of $0.5 \% \mathrm{MgSO}_{4} \cdot 7 \mathrm{H}_{2} \mathrm{O}$ and $0.1 \% \mathrm{NaCl}$, maintained at $37^{\circ} \mathrm{C}$ for $72 \mathrm{~h}$ in a shaking incubator (180 rpm). At the end of each cultivation period, the broth was centrifuged at 10,000 rpm at $4^{\circ} \mathrm{C}$ for $15 \mathrm{~min}$. The cell-free supernatant was collected as crude enzyme preparation and subjected to purification procedures.

\section{Assay of protease activity}

Extracellular protease activity was determined using a modified procedure of Fujiwara et al. [13] with 1.0\% casein in $50 \mathrm{mM}$ Tris- $\mathrm{HCl}$ buffer $\mathrm{pH} 8.0$ as substrate. The assay mixture consisted of $0.4 \mathrm{ml}$ of substrate and $0.1 \mathrm{ml}$ of enzyme solution in $50 \mathrm{mM}$ Tris- $\mathrm{HCl}$ buffer $\mathrm{pH}$ 8.0. The assay mixture was incubated at $40^{\circ} \mathrm{C}$ for $30 \mathrm{~min}$ and reaction was terminated by the addition of $2.5 \mathrm{ml}$ of $10 \%(w / v)$ trichloroacetic acid (TCA). The mixture was allowed to stand for $15 \mathrm{~min}$ and then centrifuged at 10,000 rpm for $10 \mathrm{~min}$ at $4^{\circ} \mathrm{C}$ to remove the resulting precipitate. Protease activity was determined by estimating the amount of tyrosine in the supernatant which was done by measuring the absorbance at $280 \mathrm{~nm}$. One unit of protease activity was defined as the amount of enzyme required to release $1 \mu \mathrm{g}$ of tyrosine per milliliter per minute under the specified assay conditions.

\section{Purification of protease from $B$. brevis MWB-01}

The cell-free supernatant was fractionated by precipitation with ammonium sulphate of $80 \%$ saturation. The precipitated protein collected by centrifugation was dissolved in $50 \mathrm{mM}$ Tris- $\mathrm{HCl}$ buffer $\mathrm{pH} 7.5$, and dialyzed against the same buffer at $4^{\circ} \mathrm{C}$ with three buffer changes, each for $12 \mathrm{~h}$ using Spectra/Por dialysis membrane (MWCO 3,500; Serva, Heidelberg, Germany). The resulting dialysate was centrifuged at $10,000 \mathrm{rpm}, 4^{\circ} \mathrm{C}$ for $15 \mathrm{~min}$, and the supernatant was applied on Sephadex G-200 $(1.5 \times 24 \mathrm{~cm})$ column (Sigma-Aldrich, St Louis, $\mathrm{MO}$, USA) equilibrated with $50 \mathrm{mM}$ Tris- $\mathrm{HCl}$ buffer, $\mathrm{pH}$ 7.5. The column was eluted at a flow rate of $0.5 \mathrm{ml} / \mathrm{min}$. Protease activity was assayed in all eluted fractions. The fractions (25 to 27 ) with high protease activity corresponding to the highest peak on the chromatogram were pooled, and subsequently used for characterization studies. The concentration of protein during purification studies was determined by Bradford method [14].

\section{Partial characterization of purified protease Effect of temperature on the activity and stability of protease}

The optimum temperature of purified protease was determined by measuring enzyme activity at varied temperatures $\left(30^{\circ} \mathrm{C}\right.$ to $\left.70^{\circ} \mathrm{C}\right)$. The reaction mixture was incubated 
Table 1 Identification of isolated Bacillus species

\begin{tabular}{|c|c|c|c|c|c|c|c|c|c|c|c|c|c|c|}
\hline $\begin{array}{l}\text { Isolate } \\
\text { code }\end{array}$ & $\begin{array}{c}\text { Colour/ } \\
\text { pigment }\end{array}$ & $\begin{array}{c}\text { Gram } \\
\text { reaction }\end{array}$ & $\begin{array}{c}\text { Cellular } \\
\text { morphology }\end{array}$ & $\begin{array}{c}\text { Catalase } \\
\text { test }\end{array}$ & $\begin{array}{c}\text { Oxidase } \\
\text { test }\end{array}$ & $\begin{array}{c}\text { Indole } \\
\text { production }\end{array}$ & $\begin{array}{l}\text { Motility } \\
\text { test }\end{array}$ & $\begin{array}{l}\text { Methyl } \\
\text { red test }\end{array}$ & $\begin{array}{l}\text { Voges- } \\
\text { Proskaver } \\
\text { test }\end{array}$ & $\begin{array}{l}\text { Urease } \\
\text { activity }\end{array}$ & $\begin{array}{c}\text { Citrate } \\
\text { utilization }\end{array}$ & $\begin{array}{c}\text { Starch } \\
\text { hydrolysis }\end{array}$ & $\begin{array}{c}\text { Gelatin } \\
\text { hydrolysis }\end{array}$ & $\begin{array}{c}\text { Casein } \\
\text { hydrolysis }\end{array}$ \\
\hline BWB-01 & Cream & + & Rods & + & + & - & + & - & + & - & + & + & + & + \\
\hline BWB-02 & Cream & + & Rods & + & + & + & + & - & + & + & - & + & + & + \\
\hline BWB-03 & Cream & + & Rods & + & + & - & + & - & + & - & + & + & + & + \\
\hline BWB-04 & Cream & + & Rods & + & + & - & + & - & + & - & + & + & + & + \\
\hline MWB-01 & Cream & + & Rods & + & + & - & + & + & - & - & - & + & + & + \\
\hline MWB-02 & Cream & + & Rods & + & + & - & + & - & - & - & + & + & + & + \\
\hline MWB-03 & Cream & + & Rods & + & + & - & + & - & - & - & - & - & + & + \\
\hline PFB-01 & Cream & + & Rods & + & + & - & + & - & + & - & + & + & + & + \\
\hline PFB-02 & Cream & + & Rods & + & + & - & + & + & - & - & - & + & + & + \\
\hline PFB-03 & Cream & + & Rods & + & - & - & + & - & + & - & + & + & + & + \\
\hline ADB-01 & Cream & + & Rods & + & + & - & + & - & + & - & - & + & - & + \\
\hline ADB-02 & Cream & + & Rods & + & + & - & + & - & - & - & - & + & - & + \\
\hline ADB-03 & Cream & + & Rods & + & + & - & + & - & + & - & + & + & + & + \\
\hline ADB-04 & Cream & + & Rods & + & + & - & + & + & - & - & + & + & + & + \\
\hline FWB-01 & Cream & + & Rods & + & + & - & + & - & - & - & - & - & + & + \\
\hline FWB-02 & Cream & + & Rods & + & - & - & + & - & + & - & + & + & + & + \\
\hline FWB-03 & Cream & + & Rod & + & + & - & + & - & + & - & - & + & - & + \\
\hline FWB-04 & Cream & + & Rods & + & + & - & + & - & + & - & + & + & + & + \\
\hline LFB-01 & Cream & + & Rods & + & - & - & + & - & + & - & + & + & + & + \\
\hline LFB-02 & Cream & + & Rods & + & + & - & + & - & - & - & + & + & + & + \\
\hline LFB-03 & Cream & + & Rods & + & + & - & + & - & - & - & - & + & + & + \\
\hline
\end{tabular}


Table 1 Identification of isolated Bacillus species (Continued)

\begin{tabular}{|c|c|c|c|c|c|c|c|c|c|c|c|c|c|c|}
\hline $\begin{array}{l}\text { Isolate } \\
\text { code }\end{array}$ & $\begin{array}{c}\mathrm{NO}_{3} \\
\text { Reduction }\end{array}$ & $\begin{array}{c}\text { Spore } \\
\text { test }\end{array}$ & Glucose & Xylose & Lactose & Sucrose & Maltose & Mannitol & Raffinose & Fructose & Galactose & Sorbitol & Arabinose & Organism identity \\
\hline BWB-01 & + & + & + & + & + & + & + & + & + & + & + & + & + & Bacillus polymyxa \\
\hline BWB-02 & - & + & + & - & - & - & - & - & - & - & - & - & - & Bacillus alvei \\
\hline BWB-03 & + & + & + & - & + & + & - & + & - & + & + & - & + & Bacillus subtilis \\
\hline BWB-04 & + & + & + & - & + & + & + & - & + & - & - & - & - & Bacillus cereus \\
\hline MWB-01 & - & + & + & + & - & - & - & + & - & + & + & - & - & Bacillus brevis \\
\hline MWB-02 & - & + & + & + & - & + & - & + & - & + & - & - & + & Bacillus megaterium \\
\hline MWB-03 & + & + & + & - & - & - & - & - & - & - & - & - & - & Bacillus pasterii \\
\hline PFB-01 & + & + & + & - & + & + & - & - & + & + & + & - & - & Bacillus amyloliquefasciens \\
\hline PFB-02 & - & + & + & - & - & - & - & + & - & - & - & + & - & Bacillus firmus \\
\hline PFB-03 & + & + & + & + & - & + & + & + & - & - & + & - & + & Bacillus licheniformis \\
\hline ADB-01 & + & + & + & + & + & + & + & - & + & - & - & - & + & Bacillus coagulans \\
\hline ADB-02 & + & + & + & - & - & - & - & - & - & - & - & - & - & Bacillus flavothermus \\
\hline ADB-03 & + & + & + & - & + & + & - & + & - & + & + & - & + & Bacillus subtilis \\
\hline ADB-04 & + & + & + & + & + & - & - & + & - & - & - & - & + & Bacillus circulans \\
\hline FWB-01 & + & + & + & - & + & + & - & + & + & - & - & - & - & Bacillus laterosporous \\
\hline FWB-02 & + & + & + & + & - & + & + & + & - & - & + & - & + & Bacillus licheniformis \\
\hline FWB-03 & + & + & + & + & + & + & + & - & + & - & - & - & + & Bacillus coagulans \\
\hline FWB-04 & + & + & + & + & + & + & + & + & + & + & + & - & + & Bacillus polymyxa \\
\hline LFB-01 & + & + & + & + & - & + & + & + & - & - & + & - & + & Bacillus licheniformis \\
\hline LFB-02 & - & + & + & + & - & + & - & + & - & + & - & - & + & Bacillus megaterium \\
\hline LFB-03 & - & + & + & + & - & + & - & + & - & + & - & - & + & Bacillus alcalophilus \\
\hline
\end{tabular}




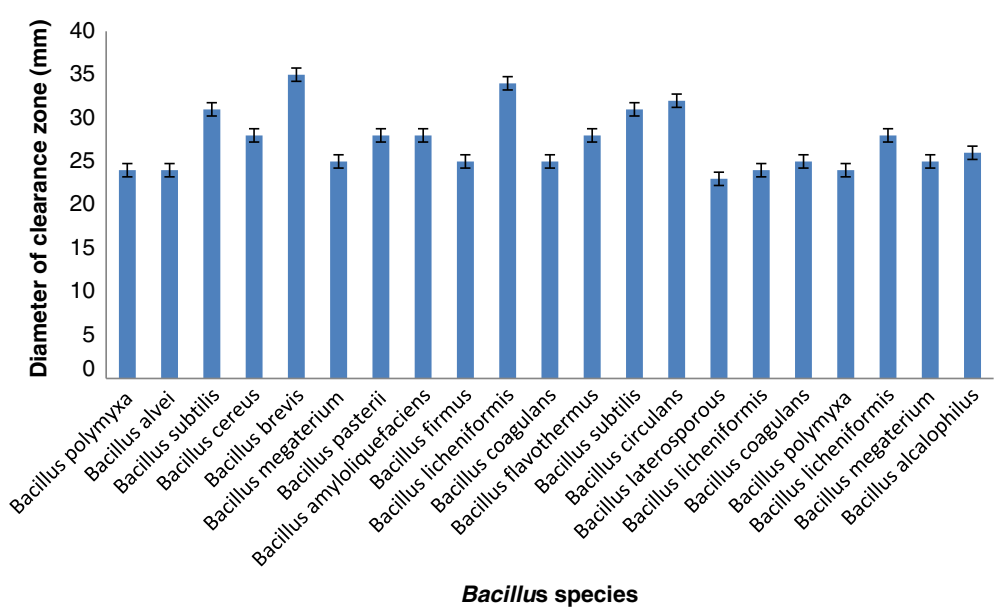

Figure 1 Zone of clearance of Bacillus species on casein agar. Proteolytic activity of isolated Bacillus species was detected by the presence of a clear zone which indicated casein hydrolysis. Symbols and bars represent mean values and standard deviations of triplicate determinations.

at respective temperatures for 30 min before determining protease activity according to the standard assay procedure earlier described. Thermal stability was determined by measuring the residual protease activity after $30 \mathrm{~min}$ and $60 \mathrm{~min}$ of pre-incubation of purified enzyme at temperatures ranging from $30^{\circ} \mathrm{C}$ to $70^{\circ} \mathrm{C}$ in $50 \mathrm{mM}$ Tris- $\mathrm{HCl}$ buffer $\mathrm{pH} 8.0$.

\section{Effect of pH on activity and stability of protease}

Effect of $\mathrm{pH}$ on activity of protease was determined by assaying for enzyme activity at different $\mathrm{pH}$ values ranging from 4.0 to 12.0 . The $\mathrm{pH}$ was adjusted using $50 \mathrm{mM}$ of the following buffer solutions: sodium acetate $(\mathrm{pH} 4.0$ to 5.0), sodium citrate ( $\mathrm{pH} 6.0$ ), Tris- $\mathrm{HCl}(\mathrm{pH} 7.0$ to 8.0) and glycine- $\mathrm{NaOH}$ (pH 9.0 to 12.0). Reaction mixtures were incubated at $40^{\circ} \mathrm{C}$ for $30 \mathrm{~min}$ and the activity of the protease was measured. To determine the effect of $\mathrm{pH}$ on stability of protease, the purified protease was incubated in relevant buffers of varying $\mathrm{pH}$ (4.0 to 12.0$)$ without substrate for $60 \mathrm{~min}$ at $40^{\circ} \mathrm{C}$. The residual protease activity was determined as previously described.

\section{Effect of inhibitors on protease activity}

Effect of inhibitors (phenylmethylsulphonyl fluoride [PMSF], $\beta$-mercaptoethanol $[\beta-\mathrm{ME}]$ and ethylene diamine tetra acetic acid [EDTA]) at $5 \mathrm{mM}$ on protease activity was determined by pre-incubating the purified enzyme solution with inhibitor for $30 \mathrm{~min}$ at $40^{\circ} \mathrm{C}$ before the addition of substrate following the standard assay procedure.

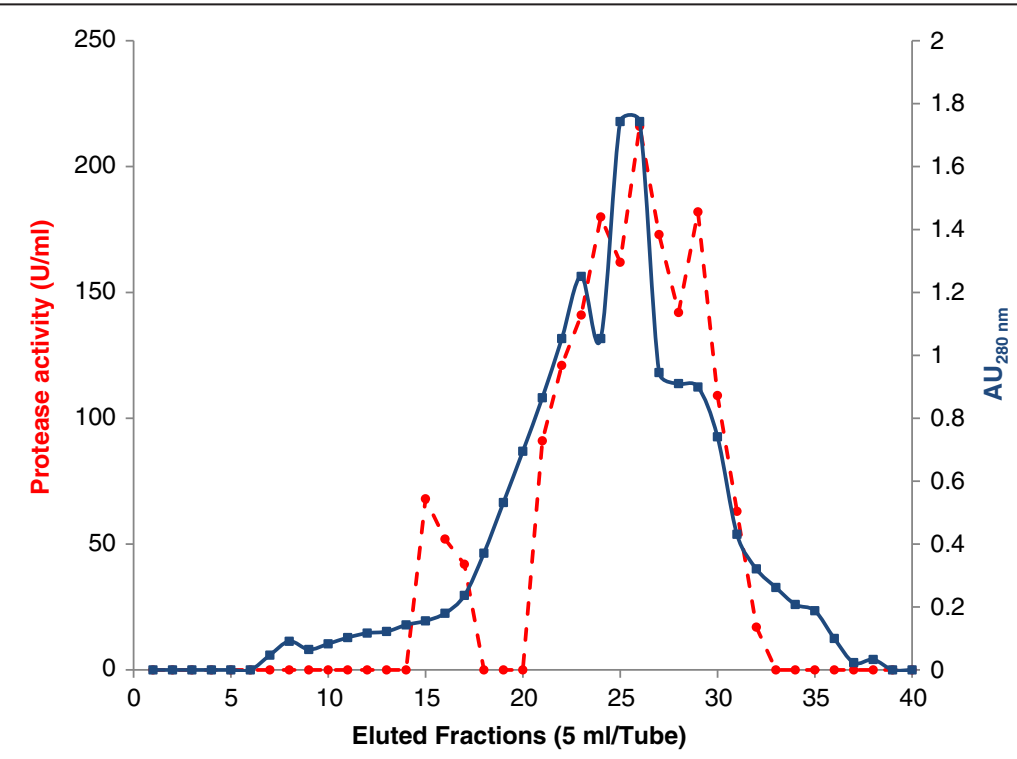

Figure 2 Protease activity in eluted fractions vs chromatogram of alkaline protease from Bacillus brevis MWB-01. 
Table 2 Purification table of protease from Bacillus brevis MWB-01

\begin{tabular}{|c|c|c|c|c|c|c|c|c|}
\hline Purification steps & Volume (ml) & $\begin{array}{l}\text { Activity } \\
(\mathrm{U} / \mathrm{ml})\end{array}$ & $\begin{array}{c}\text { Total } \\
\text { activity (U) }\end{array}$ & $\begin{array}{c}\text { Protein } \\
\text { concentration }(\mathrm{mg} / \mathrm{ml})\end{array}$ & $\begin{array}{c}\text { Total } \\
\text { protein }(\mathrm{mg})\end{array}$ & $\begin{array}{c}\text { Specific } \\
\text { activity }(\mathrm{U} / \mathrm{ml})\end{array}$ & Fold & Yield (\%) \\
\hline Crude enzyme preparation & 800 & 202 & 161,600 & 8.15 & 6412 & 25.2 & 1.0 & 100 \\
\hline $\begin{array}{l}\text { Ammonium sulphate precipitation } \\
\text { dialysed }\end{array}$ & 30 & 310 & 9,300 & 7.63 & 228.9 & 40.6 & 1.6 & 5.8 \\
\hline $\begin{array}{l}\text { Gel filtration chromatography on } \\
\text { Sephadex G-200 }\end{array}$ & 50 & 150 & 7,500 & 2.77 & 138.5 & 54.2 & 2.1 & 4.6 \\
\hline
\end{tabular}

\section{Effect of metal ions on protease activity}

The effects of metal ions on enzyme activity $\left(\mathrm{Ca}^{2+}, \mathrm{Mg}^{2+}\right.$, $\mathrm{Al}^{3+}, \mathrm{Mn}^{2+}, \mathrm{Zn}^{2+}$, and $\mathrm{Hg}^{2+}$ ) at $5 \mathrm{mM}$ was investigated by pre-incubating the purified protease with each of the metallic chlorides without substrate for $30 \mathrm{~min}$ at $40^{\circ} \mathrm{C}$. The residual protease activity was measured as previously described.

\section{Substrate specificity of purified protease}

Substrate specificity of purified protease from B. brevis MWB-01 was studied by examining proteolytic activity on protein substrates. The substrates studied were casein, bovine serum albumin (BSA), egg albumin, and gelatin. Purified protease $(0.5 \mathrm{ml})$ was added to $2.0 \mathrm{ml}$ of $50 \mathrm{mM}$ Tris- $\mathrm{HCl}$ buffer $\mathrm{pH} 8.0$ containing 1\% substrate. After incubation at $40^{\circ} \mathrm{C}$ for $30 \mathrm{~min}$, the reaction was stopped by adding $2.5 \mathrm{ml}$ of $10 \%$ TCA. Protease activity was determined by following the standard assay procedure.

\section{Detergent compatibility of purified protease}

The compatibility of $B$. brevis protease with commercial laundry detergents, Sunlight (Unilever), Ariel (Procter and Gamble), and Omo (Unilever), was studied. The effect of $5 \mathrm{mg} / \mathrm{ml}$ of each detergent on the stability of purified protease was determined. The diluted detergent solution was heated to $60^{\circ} \mathrm{C}$ for $1 \mathrm{~h}$ to denature the enzymes present in the detergent and left to cool at room temperature for $1 \mathrm{~h}$. The purified protease was incubated with the diluted detergent for $1 \mathrm{~h}$ at $40^{\circ} \mathrm{C}$ and the residual activity was determined. The enzyme activity of the control was taken as $100 \%$.

\section{Results and discussion}

Identification and screening for proteolytic activity of Bacillus species

Twenty one Bacillus species were isolated and identified using the culture, motility, morphological, and biochemical parameters (Table 1). All the species exhibited varying degrees of zones of clearance on 10\% casein agar. The proteolytic activity was detected by the presence of a clear zone which indicated casein hydrolysis. B. brevis MWB-01exhibited the highest clearance zone measuring average diameter of $35.0 \mathrm{~mm}$ (Figure 1).

\section{Purification of extracellular protease from $B$. brevis MWB-01}

The protease was purified from soluble dialysate by gel filtration chromatography as described under methods section. The chromatogram shows that the protease was eluted as a single major peak (Figure 2). Fractions

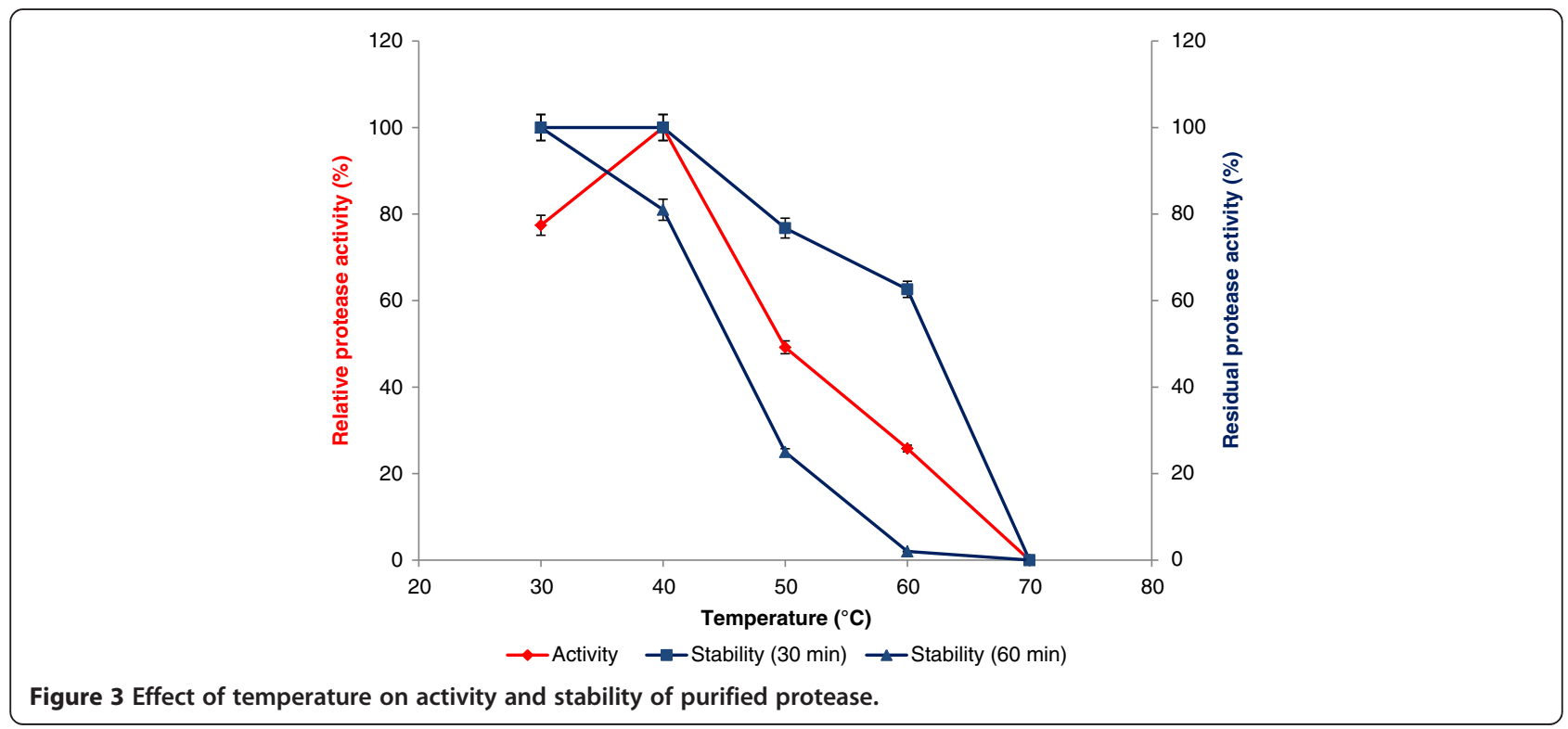




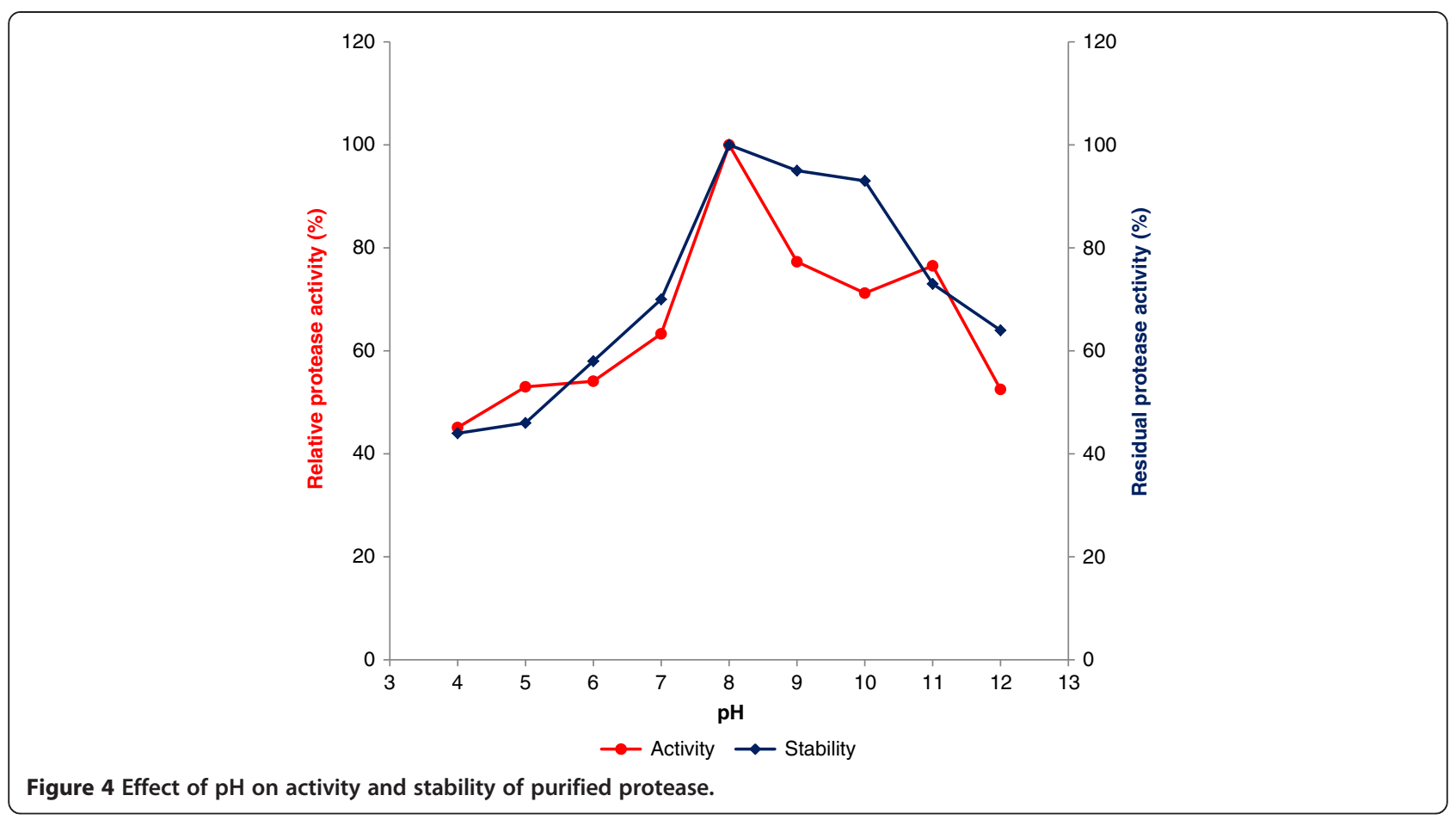

(25 to 27) with protease activity (Figure 2) were pooled and concentrated for characterization studies. The purification procedure is summarized in Table 2 , showing that the enzyme was purified 2.1-fold with a specific activity of 54.2 U/mg protein after Sephadex G-200 gel filtration chromatography. The yield of the enzyme after purification was $4.6 \%$.

\section{Partial characterization of purified protease Optimum temperature and thermal stability of protease}

The activity of the purified protease from B. brevis was determined at different temperatures ranging from $30^{\circ} \mathrm{C}$ to $70^{\circ} \mathrm{C}$. The optimum temperature for the activity of the purified protease was $40^{\circ} \mathrm{C}$ with $50 \%$ relative activity at $50^{\circ} \mathrm{C}$ (Figure 3 ). This is really unusual and surprising since some previous reports on proteases from Bacillus species have temperature optima of $50^{\circ} \mathrm{C}$ to $60^{\circ} \mathrm{C}$ [5,15-21]. The result obtained from the present study is however similar to those of reports by Feng et al. [22] and Park and Cho [23] on proteases from Bacillus pumilus strain and Bacillus sp. JSP1 which had optimum temperature of $40^{\circ} \mathrm{C}$. Banerjee et al. [24] reported a protease from a strain $B$. brevis isolated from hot springs which had optimum activity at $60^{\circ} \mathrm{C}$. The $B$. brevis under study was isolated from a mesophilic environment (beds of effluent treatment plant of a dairy industry). The observed difference in characteristics between same species of Bacillus might be strain related [25] and can also be attributed to the critical role which the source of isolation plays in determining the function of microbial species [26,27]. A decrease in relative activity of purified protease under study above $40^{\circ} \mathrm{C}$ might be due to the autolysis or denaturation of the enzyme at higher temperature [28]. The purified protease from B. brevis MWB-01 uniquely demonstrated $63 \%$ relative stability at $60^{\circ} \mathrm{C}$ after $30 \mathrm{~min}$ of preincubation at this high temperature in the absence of $\mathrm{Ca}^{2+}$ (Figure 3). It is very interesting that this purified protease exhibited good thermal stability despite a lower optimum temperature.

\section{Optimum $\mathrm{pH}$ and stability of protease}

The purified protease had optimum $\mathrm{pH}$ of 8.0 and was active over a broad $\mathrm{pH}$ range of 5.0 to 12.0 exhibiting above $70 \%$ relative activity at $\mathrm{pH} 9.0$ to 11.0 and about $54 \%$ relative activity at $\mathrm{pH} 5.0,6.0$, and 12.0 , respectively (Figure 4). This is a very remarkable characteristic of purified protease from B.brevis MWB-01 considering reports on some proteases that have higher optimum $\mathrm{pH}$ but relatively low activity at $\mathrm{pH}$ values below and above the optimum $\mathrm{pH}$ Asker et al. [29] reported an alkaline protease from Bacillus megaterium with optimum $\mathrm{pH}$ of

Table 3 Effect of inhibitors on activity of purified protease from Bacillus brevis MWB-01

\begin{tabular}{lc}
\hline Inhibitor (5 $\mathbf{~ m M})$ & Relative activity $\mathbf{( \% )}$ \\
\hline Control & 100 \\
EDTA & $7.5 \pm 0.5$ \\
B-Mercaptoethanol & $9.6 \pm 0.7$ \\
Phenylmethylsulphonyl fluoride (PMSF) & $8.3 \pm 0.5$ \\
\hline
\end{tabular}




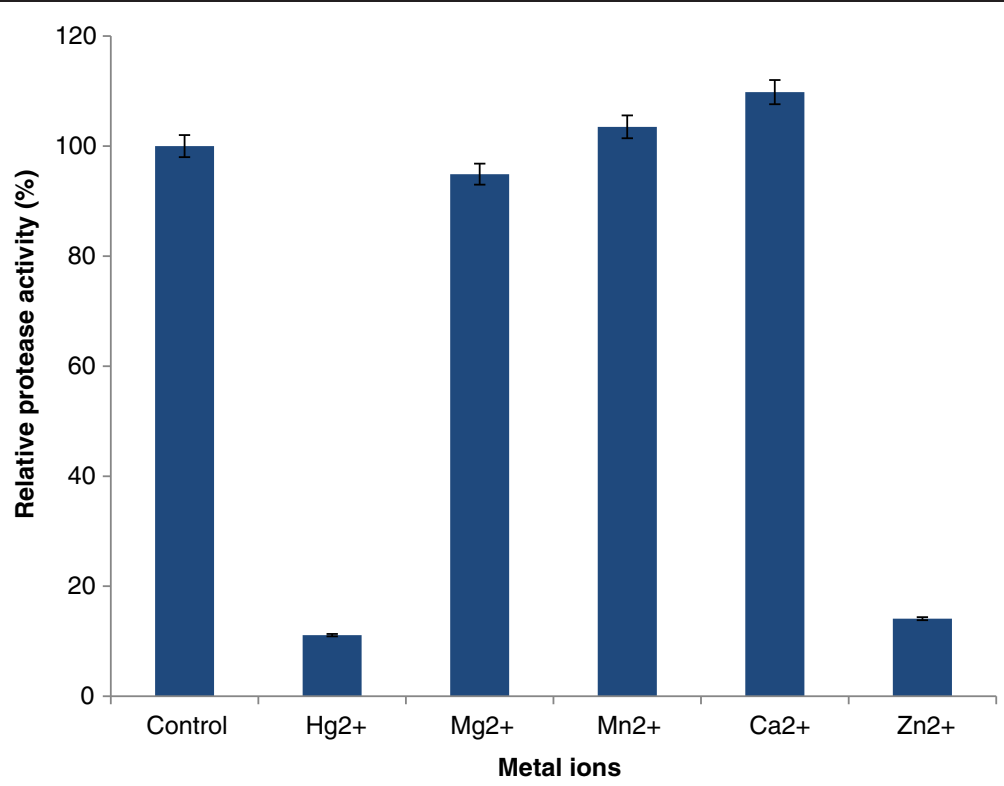

Figure 5 Effect of metal ions on activity of purified protease.

7.5 which showed relative activity of $8.0 \%$ and $10.0 \%$ at pH 5.5 and 9.0. Genkal and Tari [30] also reported an alkaline protease from a Bacillus sp. with optimum activity at $\mathrm{pH} 11.0$ and low relative activity of $20 \%$ at $\mathrm{pH} 13.0$. Bacillus pseudofirmus AL-89 had optimum $\mathrm{pH}$ of 11.0 and showed low activity at $\mathrm{pH}$ values below $\mathrm{pH} 10$ and above 11.5 [31]. High alkalinity is a desirable characteristic for proteases used in detergent formulation [7,32]. Studies on $\mathrm{pH}$ stability showed that the enzyme was very stable in the $\mathrm{pH}$ range of 7.0 to 12.0 with above $60 \%$ residual protease activity (Figure 4). It is quite interesting that the purified protease had residual activity of $93 \%$ at $\mathrm{pH} 10.0$ and $64 \%$ at $\mathrm{pH} 12$. The protease from the strain of $B$. brevis MWB-01 under study distinctively demonstrated higher stability over a broader $\mathrm{pH}$ range of 6.0 to 12.0 than the previously reported protease from another strain of $B$. brevis which had optimum activity at $\mathrm{pH} 10.5$ [24]. This exhibited characteristic by protease from $B$. brevis MWB-01 is of crucial importance in determining the suitability of proteases for use in detergents especially in ultrafiltration membrane cleaning which requires activity of protease over a broad $\mathrm{pH}$ [33].

Table 4 Substrate specificity of purified protease from Bacillus brevis MWB-01

\begin{tabular}{lc}
\hline Substrate & Relative activity (\%) \\
\hline Control (Casein) & 100 \\
BSA & $74.5 \pm 1.5$ \\
Egg albumin & $63.2 \pm 1.3$ \\
Collagen & $4.1 \pm 0.5$ \\
Gelatin & $18.4 \pm 0.7$ \\
\hline
\end{tabular}

Effect of inhibitors on activity of protease

All the inhibitors tested at $5 \mathrm{mM}$ inhibited the protease (Table 3). PMSF inhibited the protease activity by $91.7 \%$ which suggests that the purified protease from $B$. brevis MWB-01 is a serine protease. PMSF sulphonates the essential serine residue in the active site of the protease and has been reported to result in the loss of enzyme activity [34]. $\beta-$ ME inhibited protease activity by $90.4 \%$ which shows that the purified protease is not a cysteine protease which is activated in the presence of $\beta$-ME. Inhibition of the protease by $\beta$-ME might be due to denaturation of the enzyme resulting from cleavage of at least one disulfide bond that is critical to the stability of the protein and maintenance of the enzyme in its active form [35]. The enzyme lost $92.5 \%$ of its original activity in the presence of EDTA which infers that EDTA chelates metal ions at the active site of the purified protease which possibly serve as cofactors for the protease [36] confirming the enzyme is a metalloprotease.

\section{Effect of metal ions on activity of protease}

The protease activity was enhanced in the presence of $\mathrm{Ca}^{2+}$ and $\mathrm{Mn}^{2+}$ with $110 \%$ and $103.5 \%$ residual activity

Table 5 Detergent compatibility of purified protease from Bacillus brevis MWB-01

\begin{tabular}{lc}
\hline Detergent & Relative residual activity (\%) \\
\hline Control & 100 \\
Omo & $40.0 \pm 1.5$ \\
Sunlight & $76.0 \pm 2.1$ \\
Ariel & $11.0 \pm 0.9$ \\
\hline
\end{tabular}


respectively above the control (Figure 5) which indicates that these metal ions play an important role in maintaining the active site conformation of the purified protease [37]. This is similar to some previous reports on alkaline protease from Bacillus species which were activated in the presence of $\mathrm{Ca}^{2+}[17,24,28]$. However, $\mathrm{Hg}^{2+}$ and $\mathrm{Zn}^{2+}$ strongly inhibited the activity of the enzyme with $89 \%$ and $86 \%$ loss in activity when compared with the control.

\section{Substrate specificity of protease from $B$. brevis MWB- 01}

The purified protease exhibited highest level of hydrolytic activity on casein which was used as control. The enzyme hydrolysed bovine serum albumin and egg albumin showing relative activity of $74.5 \%$ and $63.2 \%$, respectively (Table 4). Gelatin and collagen were poorly hydrolysed with relative activity of $18.4 \%$ and $4.1 \%$, respectively. Earlier reports revealed that alkaline proteases showed highest activity towards casein relative to other proteins like BSA, gelatin [36,38-40]. Hydrolysis of various substrates has been reported as one of the important criteria for selection of proteases for application in laundry detergent formulation [41].

\section{Detergent compatibility of protease}

Purified protease from B. brevis MWB-01 was stable in the presence of tested commercial laundry detergents, Omo and Sunlight with relative residual activity of $76 \%$ and $40 \%$, respectively (Table 5) in the absence of $\mathrm{CaCl}_{2}$ and glycine. Similarly, protease from B. amyloliquefaciens PFB- 01 retained above $60 \%$ of its original activity in the presence of Omo [17]. The detergent compatibility of alkaline protease from B. brevis MWB-01 in the absence of $\mathrm{Ca}^{2+}$ and glycine is particularly novel considering reports on similar studies that used $\mathrm{Ca}^{2+}$ and glycine to enhance detergent compatibility of the alkaline proteases studied $[24,36]$. Purified protease from B. brevis MWB-01 was least stable in the presence of Ariel with relative residual activity of $11 \%$. The demonstrated detergent stability of protease from B. brevis MWB-01 infers that the enzyme had good compatibility with ingredients present in detergent formulation.

\section{Conclusion}

The characteristics of purified protease from $B$. brevis MWB-01 reveal that the enzyme is a thermotolerant serine alkaline metalloprotease which is compatible with detergent formulation aids. These results suggest that protease from B. brevis MWB-01 is a good bioresource for industrial applications.

\section{Competing interests}

The authors declare that they have no competing interests.

\section{Authors' contributions}

FMO conceived and designed the study and analyzed and interpreted the acquired data. AMF carried out the purification and characterization studies. Both authors participated in writing the manuscript and read and approved the final manuscript.

\section{Acknowledgements}

This research was supported by the International Foundation for Science, Sweden through research grant (F/3775-2) to Dr. Folasade M. Olajuyigbe. The authors gratefully acknowledge the contribution of Mr. S.O. Olatope and other technical staff of Biotechnology Unit, Federal Institute of Industrial Research Oshodi (F. I. I. R. O), Lagos, Nigeria in the identification of bacterial isolates.

Received: 22 May 2014 Accepted: 26 June 2014

Published: 31 July 2014

\section{References}

1. Gupta R, Beg Q, Khan S, Chauhan B (2002) An overview on fermentation, downstream processing and properties of microbial alkaline proteases. Appl Microbiol Biotechnol 60:381-395

2. Vellard M (2003) The enzyme as drug: application of enzymes as pharmaceuticals. Curr Opin Biotechnol 14:444-450

3. Pastor MD, Lorda GS, Balatti A (2001) Protease obtention using Bacillus subtils 3411 and amaranth seed meal medium at different aeration rates. Braz J Microbiol 32:6-9

4. Nascimento WC, Martins ML (2004) Production and properties of an extracellular protease from thermophilic Bacillus sp. SMIA2. Brazil. J. Microbiology 35:91-96

5. Beg QK, Gupta R (2003) Purification and characterization of an oxidation stable, thiol-dependent serine alkaline protease from Bacillus mojavensis. Enzyme Microb Technol 32:294-304

6. Breithaupt $H$ (2001) The hunt for living gold. EMBO Rep 2:968-971

7. Sanatan PT, Lomate PR, Giri AP, Hivrale VK (2013) Characterization of a chemostable serine alkaline protease from Periplaneta americana. BMC Biochem 14:32

8. Olajuyigbe FM, Kolawole AO (2011) Purification and partial characterization of a thermostable alkaline protease from Bacillus licheniformis LHSB-05 isolated from hot spring. Afr J Biotechnol 10:11703-11710

9. Olajuyigbe FM, Ehiosun KI (2013) Production oforganic solvent-tolerant and thermostable alkaline protease from Bacillus coagulans PSB-07 under different submerged fermentation conditions. Afr J Biotechnol 12:3341-3350

10. Aslim B, Yuksekdag ZN, Beyatli Y (2002) Determination of PHB growth quantities of certain Bacillus species isolated from soil. Turkish Electronic J Biotechnol Special issue:24-32

11. Vos P, Garrity G, Jones D, Krieg NR, Ludwig W, Rainey FA, Schleifer K, Whitman WB (eds) (2009) Bergey's manual of systematic bacteriology: the firmicutes, 2nd edn. New York, Springer

12. Buchanan RE, Gibbons NE (1990) Bergey's manual of determinative bacteriology, 19th edn. Williams and Wilkinsco, Baltimore

13. Fujiwara N, Masui A, Imanaka T (1993) Purification and properties of highly thermostable alkaline protease from an alkalophilic and thermophilic Bacillus sp. J Biotechnol 30:245-256

14. Bradford M (1976) A rapid and sensitive method for the quantitation of microgram quantities of protein utilizing the principle of protein-dye binding. Anal Biochem 72:248-254

15. Olajuyigbe FM, Ajele JO (2005) Production dynamics of extracellular protease from Bacillus species. Afr J Biotechnol 4:776-779

16. Olajuyigbe FM, Ajele JO (2011) Thermostable alkaline protease from Bacillus licheniformis LBBL-11 isolated from traditionally fermented African locust bean (Parkia biglobosa). J Food Biochem 35:1-10

17. Olajuyigbe FM, Ogunyewo OA (2013) Enhanced production and physicochemical properties of a commercially viable alkaline protease from Bacillus amyloliquefaciens PFB-01. Curr Biotechnol 2:73-80

18. Yu J, Jin H, Choi W, Yoon M (2006) Production and characterization of an alkaline protease from Bacillus licheniformis MH31. Agric Chem Biotechnol 49:135-139

19. Aoyama M, Yasuda M, Nakachi K, Kobamoto N, Oku H, Kato F (2000) Soybean-milk-coagulating activity of Bacillus pumilus derives from a serine proteinase. Appl Microbiol Biotechnol 53:390-395 
20. Yang J, Shih I, Tzeng Y, Wang S (2000) Production and purification of protease from Bacillus subtilis that can deproteinize crustacean wastes. Enzyme Microb Technol 26:406-413

21. Joo H-S, Kumar CG, Park G-C, Paik SR, Chang C-S (2003) Oxidant and SDS-stable alkaline protease from Bacillus clausii I-52: production and some properties. J Appl Microbiol 95:267

22. Feng YY, Yang WB, Ong SL, Hu JY, Ng WJ (2001) Fermentation of starch for enhanced alkaline protease production by constructing an alkalophilic Bacillus pumilus strain. Appl Microbiol Biotechnol 57:153-160

23. Park I, Cho J (2011) Production of an extracellular protease by an Antarctic bacterial isolate (Bacillus sp. JSP1) as a potential feed additive. Revista Colombiana de Ciencias Pecuarias 24:1

24. Banerjee UC, Sani RK, Azmi W, Soni R (1999) Thermostable alkaline protease from Bacillus brevis and its characterization as a laundry detergent additive. Process Biochem 35:213-219

25. Prescott L, Harley J, Klein D (1996) Microbiology, 3rd edn. WCB Publishers, Chicago

26. Sun $B$, Wang $X$, Wang F, Jiang $Y$, Zhang $X$ (2013) Assessing the relative effects of geographic location and soil type on microbial communities associated with straw decomposition. Appl Environ Microbiol 79:3327-3335

27. Papke RT, Ward DM (2004) The importance of physical isolation to microbial diversification. FEMS Microbiol Ecol 48:293-303

28. Ghorbel B, Sellami-Kamoun A, Nasri M (2003) Stability studies of protease from Bacillus cereus BG1. Enzyme Microb Technol 32:513-518

29. Asker MMS, Mahmoud MG, Shebwy KE, Abdelaziz MS (2013) Purification and characterization of two thermostable protease fractions from Bacillus megaterium. J Genet Eng Biotechnol 11(2):103-109

30. Genkal H, Tari C (2006) Alkaline protease production from alkalophilic Bacillus sp isolated from natural habitats. Enzyme Microb Technol 39:703-710

31. Takeda M, lohara K, Shinmaru S, Suzuki I, Koizumi J (2000) Purification and properties of an enzyme capable of degrading the sheath of Sphaerotilus natans. Appl Environ Microbiol 66:4998-5004

32. Dias DR, Vilela DM, Silvestre MPC, Schwan RF (2008) Alkaline protease from Bacillus sp. isolated from coffee bean grown on cheese whey. World J Microb Biotechnol 24:2027-2034

33. Kumar CG (2002) Purification and characterization of a thermostable alkaline protease from alkalophilic Bacillus pumilus. Lett Appl Microbiol 34:13-17

34. Gold AM, Fahrney D (1964) Sulfonyl fluorides as inhibitors of esterases. II. Formation and reactions of phenylmethane sulfonyl alpha-chymotrypsin. Biochemistry 3:783-791

35. Nelson DL, Cox MM (2004) The three-dimensional structure of proteins. In: Lehninger principles of biochemistry, 4th edn. WH Freeman \& Co, New York

36. Adinarayana K, Ellaiah P, Prasad DS (2003) Purification and partial characterization of thermostable serine alkaline protease from a newly isolated Bacillus subtilis PE-11. AAPS Pharm Sci Tech 4:56

37. Shivan $P$, Jayaraman $G$ (2011) Isolation and characterization of a metal ion-dependent alkaline protease from a halotolerant Bacillus aquimaris VITP4. Ind J Biochem Biophys 48:95-100

38. Rahman RNZA, Razak CN, Ampon K, Basri M, Yunus WMZW, Salleh AB (1994) Purification and characterization of a heat stable alkaline protease from Bacillus stearothermophilus F1. Appl Microbiol Biotechnol 40:822-827

39. Jung H-J, Kim H, Kim J-I (1999) Purification and characterization of $\mathrm{Co}^{2+}$ activated extracellular metalloprotease from Bacillus sp. JH108. J Microb Biotechnol 9:861-869

40. Yossana S, Reungsang A, Yasuda M (2006) Purification and characterization of alkaline protease from Bacillus megaterium isolated from Thai fish sauce fermentation process. Sci Asia 32:377-383

41. Gouda MK (2006) Optimization and purification of alkaline proteases produced by marine Bacillus sp. MIG newly isolated from Eastern Harbour of Alexandria. Pol J Microbiol 55:119-126

\section{doi:10.1186/s40643-014-0008-6}

Cite this article as: Olajuyigbe and Falade: Purification and partial characterization of serine alkaline metalloprotease from Bacillus brevis MWB-01. Bioresources and Bioprocessing 2014 1:8.

\section{Submit your manuscript to a SpringerOpen ${ }^{\odot}$ journal and benefit from:}

- Convenient online submission

- Rigorous peer review

- Immediate publication on acceptance

- Open access: articles freely available online

- High visibility within the field

- Retaining the copyright to your article

Submit your next manuscript at $\gg$ springeropen.com 